\title{
THE UN-INFECTIVITY OF THE PF CULTIVATED STRAIN OF TRYPANOSOMA CRUZI TO MICE. AN EVALUATION THROUGH A ONE YEAR PERIOD BY BLOOD CULTURES AND HISTOPATHOLOGY *
}

\author{
Humberto Menezes * *
}

\begin{abstract}
Trypanosoma cruzi of the cultivated PF strain when injected in mice per subcutaneous route, in adequate doses, is able to induce an efficient sterile immunization in the animals (for at least one year) as determined by whole blood cultures and histopathology.
\end{abstract}

\section{INTRODUCTION}

It is well known that each antigen presented to the lymphoid system can react with a population of immunocompetent cells, variable with the antigen used (4).

The quantity and the route used for the antigen are also of importance, giving place to an immune response which may vary from optimal to no response at all (immunotolerant condition).

I had demonstrated (14) that $3 \times 10^{2}$ live parasites of the $P F$ strain injected by subcutaneous route, with about 30 trypomastigotes, were able to give an efficient protection to $10 \mathrm{~g}$ body weight mice, against a virulent infection of Trypanosoma cruzi that killed $80 \%$ of the control animals.

This work aims to demonstrate that the route and the dose of the live $P F$ parasites are very important in obtaining a safe immune response, as applicable to any live vaccine.

\section{MATERIAL AND METHODS}

Albino mice from our Medical School Animal Facilities were used. 130 of them, all male, with an initial body weight of $10 \mathrm{~g}$ were divided in groups of 10 .

80 of these animals received by subcutaneous route $6 \times 10^{3}$ parasites of the $P F$ strain raised in Warren medium (22), dialyzated in accordance with the Nakamura technique $(20)$.

The culture meaium was put into cellophane bags immersed in 1.5 volumes of Ringer-Hartmann solution (10) adjusted with $\mathrm{NaOH}$ sol. to $\mathrm{pH} 7.5$.

The culture used as vaccine was 8 days old and the percentage of mobile forms was about $80 \%$ with $0.8 \%$ trypomastigotes, as determined in 1,000 parasites counted at ranciom in Giemsa stained smears.

The Ringer solution with flagellates was centrifuged at $1,500 \mathrm{rpm}$ for 15 minutes and the sediment suspended in sterile so-

\footnotetext{
* Presented to the $\mathrm{X}$ Congresso Brasileiro de Patologia. Curitiba, 05/09/74.

* USP. Departamento de Genética e Matemática Aplicada à Blologia da Faculdade de Medicina de Ribeirấo Preto, Sáo Paulo, 14.100 , Brasil.

Submitted to publication on 12-6-1974.
} 
lution, $\mathrm{pH} 7.0$ to give the above mentioned concentration.

The 50 other mice were kept as controls, under identical conditions.

30 days, later, 10 of the vaccinated animals and 10 controls were infected, per intraperitoneal route, with 5,000 parasites/g body weight. The infecting parasites were blood forms of the virulent $Y$ strain, maintaned through seringe passages in baby mice.

Determinations of parasitemia by the Pizzi-Brener technique (6) were performed $8,15,30$ and 60 days after the infection.

On the same day, 10 of the mice which were vaccinated 30 days earlier were anaesthetized by ether and killed by exsanguination (heart punction). The whole blood from each animal was distributed in 3 tubes with Warren medium, for culture.

After 30 days at $28^{\circ} \mathrm{C}$ temperature, the cultures were searched for Trypanosoma crizi, through microscopic examination of a drop of the medium. When negative, the examination was repeated at the end of 45 days. At this time the culture medium was centrifuged for 15 minutes at 1,500 $\mathrm{rpm}$ and the sediment examined.

45 days after the first vaccination the remaining 60 primed animals were boosted by subcutaneous route, with $5 \times 10^{5} P F$ parasite obtained by the same steps as for the first vaccine.

$60,90,120,270$ and 360 days after the first vaccination the surviving mice, from each group of 10 were killed and the whole blood cultivated and examined as described previously.

The 7 remaining animals of the 360 days vaccinated group, and the only 3 surviving mice of the corresponding intact control group, were infected with blood forms of the virulent $Y$ strain as mentioned for the first 30 days vaccinated mice.

Determinations of parasitemia were performed $8,15,30$ and 60 days after the infection. 120, 270 and 360 days after the beginning of the experiment, the remaining control groups of normal intact mice were killed and the main internal organs saved for gross and microscopic examination and for comparison with its equivalent vaccinated groups.

From the majority of the animals used in this experiment fragments of tongue, eosophagus, lungs, heart, liver, spleen, adre- nal glands, kidney, abdominal brown adipose tissue, urinary bladder, large and small intestine and skeletal muscle were fixed in $10 \%$ formalin solution. Paraffin sections of these different organs and tissues were stained by Hematoxylin \& Eosin, Mallory phosphotungstic trichromic stain and by Periodic Acid Schiff stain.

Careful search for parasites was done in a mean of 12 sections of each of the afore mentioned organs and tissues.

A detailed description of the histological findings will be the subject of another paper.

\section{RESULTS}

The results of this experimental work can be summarized as follows:

1) all the animals gave negative blood cultures from 30 to 360 days after vaccination (Table I);

2) in spite of this negativity, mice challenged at 30 and 360 days after vaccination were protected (Tables II and IV);

3) in all the vaccinated groups the heart weight was equal, or inferior, to that of the respective normal control (Table III) ;

4) the spleen weight of the 120 and 270 days vaccinated mice was greater than that of the respective intact control animals (Table III);

5) no gross alterations were observed in the heart, oesophagus, large and small intestine of the 120,270 and 360 days vaccinated animals when compared with the respective normal intact groups (Figs. 1 and 2);

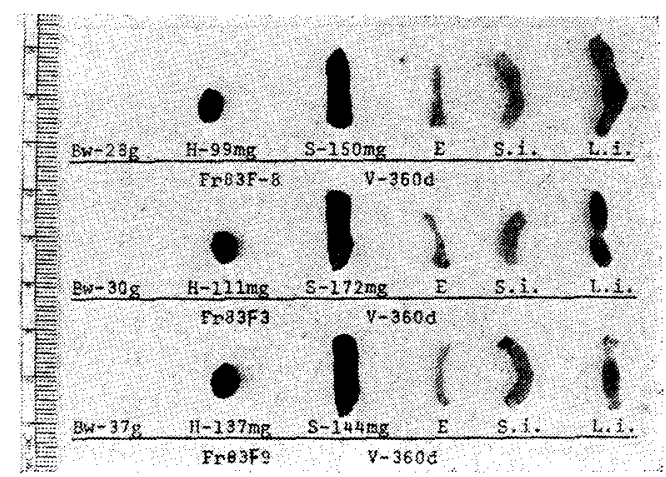

Fig. 1 - Organs of 360 days vaccinated mice showing the lighter, the intermediate and the heavier heart, No gross alterations are seen in the hollow visceras. 


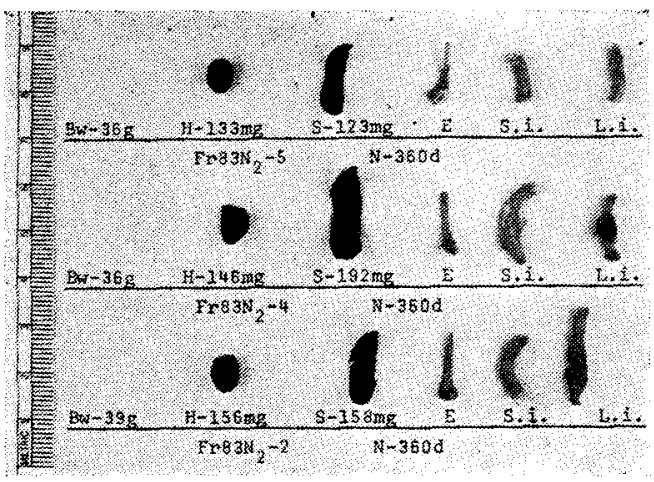

Fig. 2 - Organs of normal intact mice with the same age of those shown in the Fig. 1, ordered by the heart weight.

$\mathbf{H}=$ heart (ventricular mass) ; $\mathbf{S}=$ spleen $\mathbf{E}=$ esophagus; $\mathbf{S . 1 .}=$ small intestine and L.i. = large intestine

6) no parasites were found in the histological sections examined;

7) in all vaccinated animals a small hepatic accumulation of histiocytes, lymphocytes, plasmocytes and sometimes neutrophils was observed, but this lesion was seen, in small proportion, in normal intact mice too.

\section{DISCUSSION}

The greater effectiveness of live or attenuatea vaccines demonstrated by the greater degree of protection and the longer duration of the immunity is well known, although the enhancement of this efficacy is not yet clear (3).

The dose-response relationship between antigen concentration and the resultant immune response is also described in all modern textbooks of Immunology.

The development of immunological tolerance by "low dose" or "high dose" of antigens has been the subject of several publications $(13 ; 11,5,9 ; 19)$ and must be considered every time we intend to induce an immune response in a determined animal species with a specific antigen, particulary if the antigen is a live micro-organism.

In a previous paper, as already mentioned, I demonstrated that subcutaneous injection of $3 \times 10^{2}$ parasites of the $P F$ strain was able to induce an efficient protection in mice against a challenge that killed $80 \%$ of the control mice (14).

Later on with the use of immunosuppressive cirugs I confirmed the non viru- lence of the mentioned Trypanosoma cruzi strain $(16 ; 17)$.

Chiari (7) in a comparative study of ciifferent $T$. cruzi strains, injected in $86 \%$ of their 65 mice, $14 \mathrm{~g}$ body weight, from 2 millions to 100 millions of live $P F$ parasites per intraperitoneal route.

It must be emphasized that the investigator (7) makes reference only to the number of trypomastigotes but it represents only $5 \%$ of the total parasites injected in each animal (8).

Epimastigotes are so antigenic as trypomastigotes $(12 ; 18)$ and cannot be neglected in an experiment like this.

30 days after those massive trypanosomose injections Chiari (7) finds no patent parasitemia, refers to no mortality, presents no histologic findings and obtains a mean of $60 \%$ of positive blood cultures.

Considering only the animals inoculated with the $P F$ strain whose blood was cultivated in LIT medium (Tables V and VI of the Chiari's paper (7) one can see that 2 millions of intraperitoneal injected parasites gave $75 \%$ of positive blood cultures $(3 / 4)$, the same percentage obtained with the intraperitoneal injection of 100 millions of the same parasites (15/20).

So it is admissible to consider another cause than the infectivity of the parasites as responsible for the positivity of the biocd cultures. In consequence of the enormous amount of parasites injected and the route employed, the most probable argument must be the development of an immunotolerant state.

It is apropriate to call attention, once more, to the fact that the existence of a trypanosome positive blood culture, particulary in these circumstances, is no acceptable evidence of its pathogenicity. This must involve: 1) the rate of infection (injected animals/infected animals); 2) the duration of the prepatent period; 3 ) the intensity of the parasitemia; 4) the duration of the acute phase; 5 ) the rate of mortality and 6) the degree of tissular parasitism (21).

Hungerer (12) injecting epimastigotes of $T$. cruzi into thymusless nu/nu mice got positive blood cultures with no other evidence of infection.

It is the subject of long observation and of experimental data too, that the antigens, specially live micro-organisms, are 
used in a narrow range of doses to have the least harmful effect possible on the patent. When the immunologists recommend $3 \times 100 \mathrm{mg}$ of $\mathrm{BCG}$ by oral route to a child or $50 \mathrm{mg}$ per intradermic route, the pediatrician must not use $3,000 \mathrm{~g}$ or $500 \mathrm{mg}$ respectively because the results would surely be disastrous. Every internist knows the danger of emploing, even in optimal doses, live vaccines during the use of immunodepressive drugs or in the cases of infectious disease.

Another point in the work of Chiari (7) on which I would like to make some remarks is that concerned with the culture medium.

He states that the LIT medium gives better results than the Warren medium. In an unpublished work, Rosa Ribeiro and myself, working with 60 albino mice injected by subcutaneous route with $5 \times 10^{7} P F$ parasites, made cultures of blood and macerate of heart, spleen and liver in both meåia.

The cultures were done in groups of 10 animals from 15 to 120 days after vaccination.

We got only positive cases in the Warren medium $(8 \%)$ and 4 in the LIT $(7 \%)$. 3 of the positive cases were obtained in the 15 day of vaccination. One case was detected by the LIT medium and not by the Warren but on the other hand 2 were positive in the Warren and negative in the LIT medium.

Better results were seen by Albuquerque et als (1) from the Warren than the LIT, comparing the results of human chronic cases of Chagas disease.

So I did not find any advantages in substituting the Warren by the LIT meciium.

\section{CONCLUSIONS}

From the data of this experiment and of several others $(14 ; 18)$ I can conclude that the $P F$ cultivated strain of Trypanosoma cruzi, when given by the appropiate route, in adequate doses (as it is also done in all other live vaccines), is able to induce an efficient sterile immunization in mice against a challenge with a virulent strain of the same parasite. This immunity remains for a long time-one year at least-for mice.

No megas could be detected in the long term vaccinated animals whose internal organs, except the spleen in two groups, were similar or smaller than those of the intact normal mice of the same age, maintained under the same food and ambiental conditions.

\section{$R E S U M O$}

Trypanosoma cruzi da cepa PF quando injetado em camundongos, por via subcutânea, em doses adequadas, produz imunidade eficiente e duradoura (um ano pelo menos), sem que se tenha podido identificar infeç̧áo ou infecção. -doença por meio de hemoculturas e estudos histopatológicos.

O Autor tece consideraçôes sobre resultados aparentemente discrepantes obtidos por outro pesquisador (7-8), concluindo pela impropriedade do método utilizado por este para obter um estado de imunidade esteril.

Corroborando suas observaçóes e experimentações anteriores, o Autor conclue pela eficácia da cepa referida como meio de se obter imunização ativa contra a tripanosomose americana experimental.

\section{REFERENCES}

1. ALBUQUERQUE, R.D.R.; FERNANDES, L.A.R., FUNAYAMA, G.K., FERRIOLI F.O, F. \& SIQUEIRA, A.F. - Hemoculturas seriacias com o meio de Warren em pacientes com reação de Guerreiro \& Machado positiva. Rev. Inst. Med. Trop. Säo Paulo, 14: $1-5,1972$.
2. BARRET, J.T. - Textbook of Immunology. The C.V. Mosby Co. St. Louis. 1970.

3. BELLANTI, J.A. - Immunology. W. B. Saunders. Philadelphia. 1971.

4. BIER, O., MOTA, I., da SILVA, W.D. 
\& VAZ, N.M. - Imunologia básica e aplicada. Guanabara - Koogan, Rio, 1973.

5. BIRO, C. - Tolerância Imunológica. Rev. Lat. Amer. Microbiol, 12: 237$-242,1970$.

6. BRENER, Z . -- Contribuição ao estudo da terapêutica experimental da doença de Chagas. Fac. Odont. Farm. Univ. M. Gerais. Belo Horizonte. Tese, 1961.

7. CHIARI, E. - Infectivity of Trypanosoma cruzi metacyclic trypomastigotes from cultures kept in laboratory for different periods of time. Rev. Inst. Med. Trop. São Paulo, 16: 61-67, 1974.

8. CHIARI. E. - Growth and differentiation of Trypanosoma cruzi cultures forms kept in laboratory for difrerente periods of time. Rev. Inst. Med. Trop. São Paulo, 16: 81-87, 1974.

9. CROWLE, A.J. -The role of immunologic tolerance in immunologic response. Ann. Allergy, 24: 195-214, 1966.

10. HARTMAN, A.F. - Theory and practice of parenteral fluid administration. J.A.M.A., 103: 1349-1354, 1934.

11. HUMPHREY, J.H. \& WHITE, R.G. Imunologia Médica. Guanabara-Koogan, Rio, 1972.

12. HUNGERER, Y.D. - Immunology of experimental Chagas disease. Conferência Dep. Med. Prev. Pac. Med. Univ. São Paulo, 11-2-1972.

13. LANDY, M \& BRAUN, W. - Ed. Immunological tolerance. Academic Press, N. York, 1969.

14. MENEZES, H. - Imunização de camundongos com "vacina" viva aviru- lenta de Trypanosomaacruzi. I Ensaio de avaliação cio menor inóculo eficiente. Rev. Soc. Bras. Med. Trop. 3: 297-303, 1969.

15. MENEZES, H. - III. The avirulence of the cultivated $\mathrm{Y}$ strain of Trypanosoma cruzi. Rev. Inst. Med. Trop. São Paulo, 13: 14-17, 1971.

16. MENEZES, H. - The avirulence of the cultivated $\mathrm{Y}$ strain of Trypanosoma cruzi. IV - The effect of immunosuppressive agents in mice. Rev. Soc. Bras. Med. Trop., 4: 213-233, 1972.

17. MENEZES, $H$. - The avirulence of the cultivated PF strain of Trypanosoma cruzi: VII - The effect of antilymphocytic serum in dogs. Rev. Soc. Bras. Med. Trop. (in press).

18. MENEZES, H. - The protective effect of the epimastigotes forms of the $P F$ strain of Trypanosoma cruzi against a virulent homologous infection. Rev. Soc. Bras. Med. Trop. (in press).

19. MITCHISON, N.A. - Introduction of immunological paralysis in two zones of dosage. Proc. Roy. Soc. (Biol.), 161: 275-292, 1964.

20. NAKAMURA, M. - Cultivation of Trypanosoma cruzi in a Protein-Free dialysate medium. - Proc. Soc. Exp. Biol. Med., 125: 779-780, 1967.

21. RIBEIRO, R.D. - Contribuição para o estudo da infecção natural de roedores brasileiros pelo Trypanosoma cruzi. Fac. Farm. Odonto. Rib. Preto. Tese. 1971.

22. WARREN, L.G. - Metabolism of Schizotrypanum cruzi, Chagas. I Effect of culture age and substrate concentration on respiratory rate. $J$. Parasitol., 46: 529-539, 1960. 


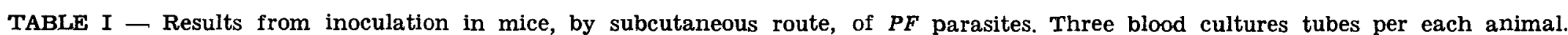

\begin{tabular}{|c|c|c|c|c|c|c|c|}
\hline \multirow{2}{*}{$\begin{array}{c}\text { Days } \\
\text { after } \\
\text { vaccination }\end{array}$} & \multirow{2}{*}{$\begin{array}{l}\text { number } \\
\text { of } \\
\text { animals }\end{array}$} & \multirow{2}{*}{$\begin{array}{c}1 \text { st dose } \\
6 \times 10^{3} \\
\text { parasites } \\
\text { s. c. route }\end{array}$} & \multirow{2}{*}{$\begin{array}{l}2^{\text {nd dose }} \\
5 \times 10^{5} \\
\text { parasites } \\
\text { s. c. route }\end{array}$} & \multicolumn{2}{|c|}{$\begin{array}{l}\text { Blood culture (Warren medium) } \\
\text { (Animal positive/inoculated) }\end{array}$} & Histopathology & \multirow{2}{*}{ Obs. } \\
\hline & & & & after 30 days & after 45 days & in tissues & \\
\hline 30 & 10 & 10 & & $0 / 10$ & $0 / 10$ & - & \\
\hline 60 & 10 & 10 & 10 & $0 / 10$ & $0 / 10$ & 一 & \\
\hline 90 & 10 & 10 & 9 & $0 / 9$ & $0 / 9$ & 一 & $\begin{array}{l}1 \text { died } 4 \text { days } \\
\text { after } 1^{\text {st }} \text { vaccine }\end{array}$ \\
\hline 120 & 10 & 10 & 9 & $0 / 7$ & $0 / 7$ & 一 & $\begin{array}{l}1 \text { died } 6 \text { days } \\
1 \text { died } 85 \text { days } \\
1 \text { died } 90 \text { days } \\
\text { after } 1 \text { st vaccine }\end{array}$ \\
\hline 270 & 10 & 10 & 9 & $0 / 9$ & $0 / 9$ & 一 & $\begin{array}{l}1 \text { died } 1 \text { day } \\
\text { after } 1^{\text {st }} \text { vaccine }\end{array}$ \\
\hline 360 & 10 & 10 & 9 & $0 / 8$ & $0 / 8$ & - & $\begin{array}{l}1 \text { died } 6 \text { days } \\
1 \text { died } 360 \text { days } \\
\text { after } 1^{\text {st }} \text { vaccine }\end{array}$ \\
\hline Total & 60 & 60 & 46 & $0 / 53$ & $0 / 53$ & $0 / 53$ & \\
\hline
\end{tabular}


TABLE II - Parasitemia and mortality rate from vaccinated * and control mice infected, intraperitoneally, with 5,000 parasites/g, " $\mathrm{Y}$ " virulent strain of Trypanosoma cruzi.

\begin{tabular}{|c|c|c|c|c|c|c|}
\hline \multirow{2}{*}{ Mice } & \multicolumn{5}{|c|}{$\begin{array}{l}\text { Parasites in } 5 \mathrm{~mm}^{3} \text { of blood } \\
\text { Days after infection }\end{array}$} & \multirow{2}{*}{ Obs. } \\
\hline & & 8 & 15 & 30 & 60 & \\
\hline 1 & vaccinated & 140 & 280 & 0 & 0 & \\
\hline 2 & $"$ & 0 & 0 & 0 & 0 & \\
\hline 3 & $"$ & 3,080 & & & & Died \\
\hline 4 & $"$ & 525 & 210 & 0 & 0 & \\
\hline 5 & $"$ & 480 & 2,345 & 0 & 0 & \\
\hline 6 & $"$ & 525 & 525 & 0 & 0 & \\
\hline 7 & $"$ & 4,375 & 2,170 & 0 & 0 & \\
\hline 8 & $"$ & 315 & 0 & 0 & 0 & \\
\hline 9 & $"$ & 630 & & & & Died \\
\hline 10 & $"$ & 480 & 0 & 0 & 0 & \\
\hline MEDIAN & & 502 & 245 & 0 & 0 & \\
\hline $\begin{array}{c}\text { Mortality } \\
\text { (cumulative) }\end{array}$ & & $0 \%$ & $20 \%$ & $20 \%$ & $20 \%$ & \\
\hline 1 & control & 4,375 & 2,380 & 140 & 0 & \\
\hline 2 & $"$ & 3,920 & 1,990 & & & Died \\
\hline 3 & $"$ & 17,500 & & & & Died \\
\hline 4 & $"$ & 10,500 & 2,870 & & & Died \\
\hline 5 & $"$ & 17,500 & 2,940 & 0 & 0 & \\
\hline 6 & $"$ & 14,000 & 3,570 & 315 & 0 & \\
\hline 7 & $"$ & 4,234 & 2,730 & & & Died \\
\hline 8 & $"$ & 4,320 & & & & Dieđ \\
\hline 9 & $"$ & 5,670 & 3,780 & & & Died \\
\hline 10 & $"$ & 4,025 & & & & Died \\
\hline MEDIAN & & 5,022 & 2,870 & 0 & 0 & \\
\hline $\begin{array}{c}\text { Micrtality } \\
\text { (cumulative) }\end{array}$ & & $0 \%$ & $30 \%$ & $70 \%$ & $70 \%$ & \\
\hline
\end{tabular}

* Each anlmal received $6 \times 10^{3} P F$ parasites by subcutaneous route 30 days before challenge. 
TABLE III - Vaccinated and normal mice maintained as controls for mortality rate, body, heart and spleen weight and for the morpholcgy of the hollow internal viscera.

\begin{tabular}{|c|c|c|c|c|c|c|}
\hline \multirow{2}{*}{$\begin{array}{l}\text { Number } \\
\text { of } \\
\text { mice }\end{array}$} & \multirow{2}{*}{$\begin{array}{l}\text { Initial } \\
\text { body } \\
\text { weight } \\
\pm \text { s.d. }\end{array}$} & \multicolumn{2}{|c|}{ Duration of } & \multirow{2}{*}{$\begin{array}{l}\text { Final body weight } \\
(\mathrm{g}) \\
\text { mean } \pm \text { s. d. }\end{array}$} & \multirow{2}{*}{$\begin{array}{l}\text { Heart weight } \\
\text { (mg) } \\
\text { mean } \pm \text { s. d. }\end{array}$} & \multirow{2}{*}{$\begin{array}{l}\text { Slpeen weight } \\
(\mathrm{mg}) \\
\text { mean } \pm \text { s. d. }\end{array}$} \\
\hline & & $\begin{array}{l}\text { Control } \\
\text { (days) }\end{array}$ & $\begin{array}{l}\text { Vaccin. } \\
\text { (days) }\end{array}$ & & & \\
\hline 10 & 10 & 120 & & $28.72 \pm 0.56$ & $107.80 \pm 10.30$ & $218.30 \pm 111.35$ \\
\hline 7 & 10 & & 120 & $27.98 \pm 2.65$ & $112.28 \pm 11.73$ & $378.43 \pm 112.21$ \\
\hline 7 & 10 & 270 & & $32.43 \pm 4.12$ & $126.57 \pm 23.83$ & $154.28 \pm 42.39$ \\
\hline 9 & 10 & & 270 & $30.32 \pm 3.38$ & $124.87 \pm 22.26$ & $226.11 \pm 61.83$ \\
\hline 7 & 10 & 360 & & $36.57 \pm 2.88$ & $145.28 \pm 8.75$ & $145.71 \pm 31.75$ \\
\hline 7 & 10 & & 360 & $30.71 \pm 3.40$ & $114.86 \pm 12.39$ & $159.71 \pm 31.49$ \\
\hline
\end{tabular}


TABLE IV - Parasitemia and mortality rate from vaccinated ${ }^{*}$ and control animals infected, intraperitonealy, with 5,000 parasites/g, $Y$ virulent strain of Trypanosoma cruzi.

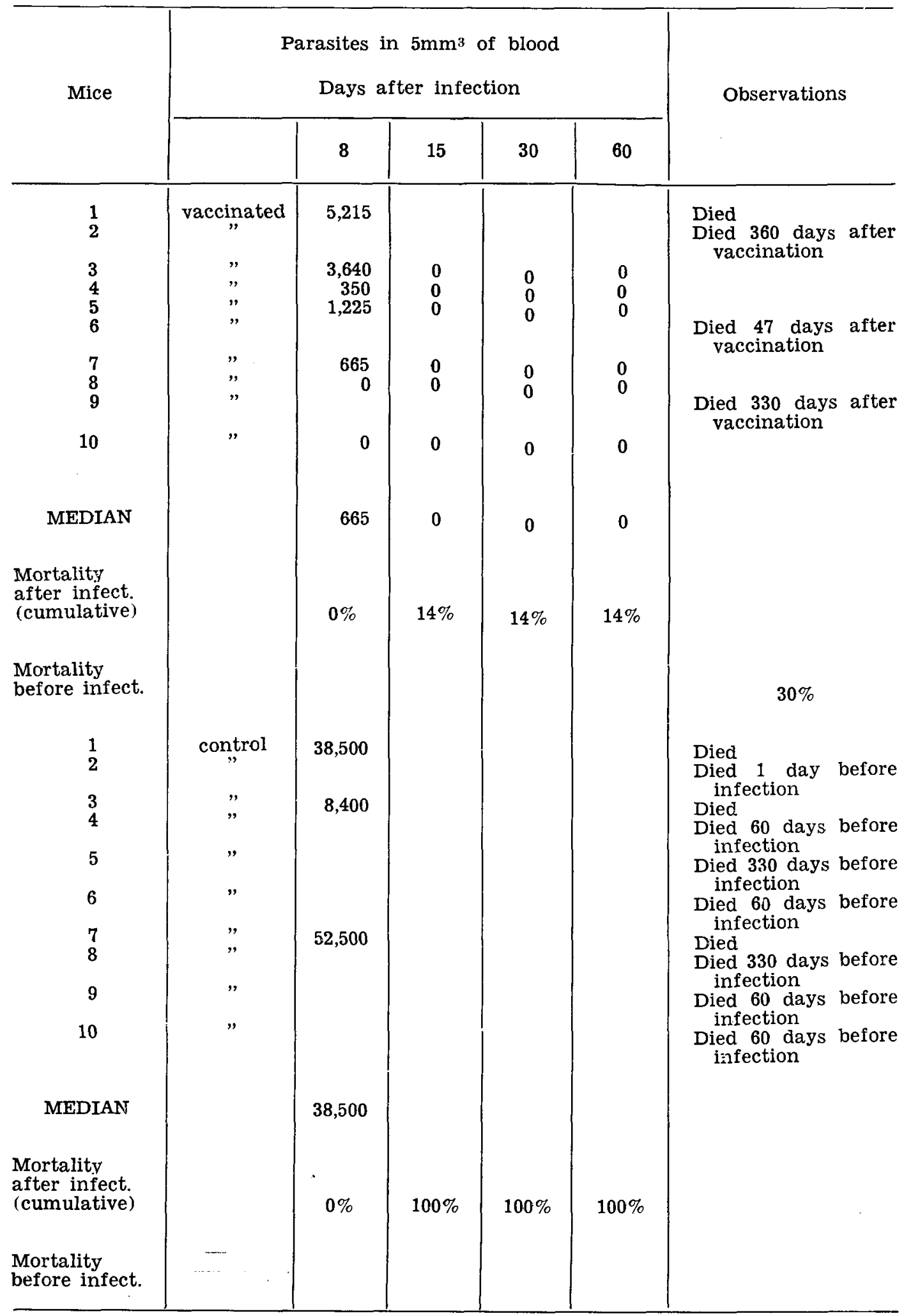

* Each vaccinated animal recelved $6 \times 10^{3} P F$ parasites, 45 days later was boosted with $5 \times 10^{5}$ flagellates of the same strain and challenged, after 360 days. 